INTERNATIONAL JOURNAL OF RESEARCHES IN BIOSCIENCES, AGRICULTURE AND TECHNOLOGY (c) VISHWASHANTI MULTIPURPOSE SOCIETY (Global Peace Multipurpose Society) R. No. MH-659/13(N)

\title{
LIGHT MICROSCOPIC STUDIES OF POLLEN GRAINS BY ACETOLYSIS METHOD
}

\author{
U. G. Basarkar \\ P. G. Departme nt of Botany, G. E. Society's HPT Arts RYK Science College, Nasik, Maharashtra \\ Email-padmakarpaithankar@gmail.com
}

Abstract:

The present investigation deals with pollen morphological study of flowering plants from Ramshej Fort, Mhasrul, Nasik, Maharashtra during the period of January 2016 to December 2016. Fresh flowers from diffe rent plants collected early in the morning before anthesis. Collected pollen grains treated by acetolysis technique and obse rved under light microscope for pollen morphological studies. The purpose of this survey work was to collect the pollen materials from different plants growing in the field and study of diffe rent pollen parameters such as shape, size, colpi and exine ornamentation.

Pollen grain from plants such as Parthenium hysterophorous ,Alternan thera cicilis Hibiscus pandurifo rmis ,Plumbago zelanica, Malvas trum spp. ,Lantana camera ,Argyreaya species ,Cassia occidentalis, Brassica campestris ,Laiunea sarmenosa Cordiospermum heicabum, Merremia species ,Vernonia cineraria ,Trid ax procumbens ,Zenia pinnata ,Smithea spp. ,Ribulus tenestris, Desmodium scopiurus, Macroptilium uniflorum,Euphorbia geniculata, Ageratum conyzoides, ,Peristrophe paniculata,Borrahavia diffusa, Ipomea marginata, Sonchus oleraceus ,Oxalis coniculata, Synedrela nudiflora, Euphorbia hirta, Cantariu m meyeriwe re collected.

Total 30 types of pollen grains from different plants collected. Out of the se pollen types 7 belonging to Aste raceae, 3 from Malvaceae, 3 from Convolvulaceae, 3 from Fabaceae, 2 from Euphorbiaceae and one from Amaranthaceae, Plumbaginaceae, Verbe naceae, Caesalpinaceae, Brassicaceae, Sapinadaceae, Zygophylacaeae, Boraginaceae, Acanthaceae, Steraceae, Oxalidaceae and Gentiaceae family respectively. Among the collected taxa 9 shows trizonocolporate type, 4 shows polyzono heterocolporate type and one exhibits te trazonocolporate type of pollen grains. Te trazonocolporate type of pollen grain is found in Argyreya species.

On the basis of pollen parameters the present investigated taxa like Parthenium hysterophorus, Plumbago, Lantana camara, Argyra spp., Cassia occidentalis and Brassica campestris having tricolporate pollen grains may be considered as in advanced status whe reas Acacia auriculiformis has primitive status in scale of evolution. The pre sent study is useful in the pre paration of a comple te pollen calendar in different seasons of the area under investigation. The colporate structures could be noticed very clearly in acetolysed pollen grains. The pre pared pollen slides of the taxa investigated may be used as refe rence slides for identifying the pollen grains captured from air.

\section{INTRODUCTION}

Palynology, the science of pollen obtained real impetus after the discovery of the microscope. This is logical because the pollen grains are extremely tiny particles comparable to dust particles which cannot be seen by the naked eye. Pollen grain come in an infinite variety of shapes with complex surface orname ntation and occurs on almost every surface in nature. Discove ry of microscope by Robert Hooke in 1665 was a landmark in the development of science particularly palynology subsequent improvement in microscopy accelerated the study of pollen grains especially finer structure of pollen wall and its varied ornamentation patterns.

The pollen grains are smallest unit of the plants, which contain so many characters of taxonomic \& phylogenetic importance. The shape $\&$ size of the pollen grains, germinal furrows \& the number of germ pores are important taxonomic features, which are taken into conside ration in clas sification of plants.

Light microscopic studies give information on the extreme subsurface morphology \& not the extreme surface of pollen grains. In recent years the scope of pollen morphology has widened with advent of scanning electron microscopy (SEM) \& with regards to unipalynous taxa, particularly the understand ing of finer morphology is of fundamental of exine surface \& ornamentation pattern of the pollen grains.

Now a days study of pollen is an important area of research. Various pollen morphological features such as symmetry, shape, apertural pattern and exine configuration are very conservative features for the taxonomic assessment of the plant. Moreover some plants growing in the surroundings cause respiratory troubles or allergy in human beings, the pollen grains of which are responsible for allergy.

Pollen are ubiquitous in nature unlike other plant parts they are highly resist to decay they occur buried deep in rocks ground surface water and air indoor and outdoor including the upper atmosphere. Besides this pollen find their way through nasal and oral cavity to the digestive tract of humans and animal causing various degrees of discomfort. Pollen has the longest geological history as they are well preserved in rock as old as 400 million years. On account of these unique characters pollen and spores are often referred as nature's fingerprint of plants (Bera et. al., 2007: Singh, 2004).

Pollen biology encompasses pollen production, their transfer to the stigma or pollination and details of pollen pistil interaction leading to fertilization and seed set. Any break in these sequential events affects seed and fruits 
se t. Pollen biological studies are a pre re quisite for any program aimed at optimization and improvement of the yield of crop plant. Pollination ecology is also a part of pollen biology which involves the study of various aspects dealing with efficient pollination (Chauhan, 2006). Pollen biotechnology is one of the techniques employed to study pollen biology for crop production and improvement. Pollen biotechnology is one of the most challenging areas of plants reproductive biology and plays an important role in crop improvement programs (Perveen, 2006).

No survey is carried out with re spect to pollen morphological studies from Ramshej Fort, Mhasrul, Nasik, Maharashtra. Therefore this work will be useful for preparation of pollen calendar.By considering immense importance of pollen morphological studies in relation to allergy, present work is undertaken for light microscopic studies of different pollen grains

\section{MATERIAL AND METHODS}

\section{a) Collection of pollen grains and identification of plants species}

Fresh flowers of different plant species collected early in the morning before anthesis from Ramshej fort,Mhasrul, Nashik Maharashtra during the period of January 2016 to December 2016.

Plants such as Parthenium hysterophorous, Alternanthera cicilis Hibiscus panduriformis ,Plumbago zelanica ,Malvastrum spp. ,Lantana camera ,Argyreaya species ,Cassia occidentalis, Brassica campestris ,Laiunea sarmenosa Cordiospermum heicabum ,Merremia species ,Vernonia cineraria ,Tridax procumbens ,Zenia pinnata ,Smithea spp. ,Ribulus tenestris, Desmodium scopiurus, Macroptilium uniflorum ,Euphorbia geniculata, Ageratum conyzoides ,Peristrophe paniculata ,Borrahavia diffusa ,Ipomea marginata, Sonchus oleraceus, Oxalis coniculata, Synedrela nudiflora ,Euphorbia hirta ,Cantarium meyeri were collected and pollen morphology was studied by acetolysis method (Erd tman, 1952).

\section{b) Preparation of glycerin jelly}

Pollen from the known plant is shaken on to a microscope slide or the anthers are placed on a slide and a drop of ethe $r$ is added to disperse the pollen. Any visible particles that are larger than the pollen grains should be removed. Drops of ether are then carefully run over the pollen from a pipette. This will dissolve any oil in the pollen and carry it to one side where it can wipe off or whe re the solution can be absorbed by the tissue. Then two drops, one of warmed, stained jelly and another of unstained jelly, are placed on the polle $n$ by means of a glass rod. A cover slip is carefully positioned on top, one edge lowe red first to avoid trapping air bubbles. The slide is left on a warm plate for about ten minutes. The jelly should be just sufficient to fill the space under the cover slip

Glycerin jelly is prepared by dissolving seven gm. of gelatin in $42 \mathrm{ml}$ of cold distilled water. $50 \mathrm{ml}$ of glycerin is added, warmed ge ntly and stirred until it is dissolved; $0.5 \mathrm{gm}$. of phenol is then added to prevent the growth of mould. To prepare the stained glyce rin jelly, $0.1 \mathrm{gm}$. of basic fuchsine is dissolved in $10 \mathrm{ml}$ of alcohol (methylated spirit). This stain is then added dropby-drop to the glycerin jelly until a clear pink color is produced.

A few hrs. later, when the jelly has finally set, any surplus should be cleaned off with water. The cover slip is the $n$ sealed along the edges with clear nail varnish or paraffin wax. Thus treated, the slides will last for many years.

c) Acetolysis of pollen grains (Erdtman, 1952)

The fresh material consisting of full flowers or anthers were placed in test tube, crushed with glass rod in $70 \%$ alcohol and then filtered. The sediment left in the test tube after decantation of alcohol is covered with glacial acetic acid, centrifuged and the sediment covered with fresh ace tolysis mixture prepared by mixing 9 parts of acetic anhydride and 1 part of concentrated sulphuric acid, the late $r$ being put drop by drop. The tube with the mixture is placed in a hot water bath until the pollen grains become brownish black. The test tube was then cooled and centrifuged and this centrifuged acetolysis mixture was decanted and again centrifuged with glacial acetic acid and then decanted. This procedure was repeated 2-3 times with distilled water. After decanting water, $50 \%$ glyce rin was added and centrifuged, small quantity of glycerin jelly was placed on warming the slide, gently pollen sample was added from test tube; it was the $n$ covered with cover slip, the slide thus was sealed with paraffin wax and then kept for microscopic observation.

The microphotographs of the pollen grains were taken by a microscope (Make Olympus and Mode1-CX 2 li and Number $12 \mathrm{M} 268)$. The terminology of pollen is followed from Bhattacharya et. al. (2009), Erdtman (1952) Faegri (1964), Kre mp (1965) and Moore and Webb (1978). 


\section{RESULT AND DISCUSSION}

The present investigation deals with pollen morphological studies of flowering plants growing atRamshej fort,Mhasrul, Nashik during the period of January 2016 to Dece mber 2016. Fresh flowe rs from different plants collected early in the morning before anthesis. Collected pollen grains treated by acetolysis technique and observed under light microscope for pollen morphological studies. The purpose of this survey work was to collect the pollen materials from different plants growing in the field and study of different pollen parameters such as shape, size, colpi and exine ornamentation.

Total 30 types of pollen grains from different plants collected which are tabulated in Table -1 and Photoplates I-V, Photo no. -30 Out of these pollen types 7 belonging to Asteraceae, 3 from Malvaceae, 3 from Convolvulaceae, 3 from Fabaceae, 2 from Euphorbiaceae and one from Amaranthaceae, Plumbaginaceae, Verbenaceae, Caesalpinacaea, Brassicaceae, Sapinadaceae, Zygophylacaeae, Boraginaceae, Acanthaceae, Asteraceae, Oxalidaceae and Gentiaceae family respectively.

The present study is useful in the preparation of a complete pollen calendar in diffe rent seasons of the area under investigation. A pollen calendar is useful for allergy clinics (Tilak, 2012). Almost all the plants such as Argyeaya species, Cassia occidentals, Brassica campestris shows 3-colporate type of pollen grains (Keshavarzi et. al., 2012). Earlier Agashe (1975) reported the pollen morphology of Parthenium hysterophorus by light microscopic studies

In the previous study (Pal, 1992; Pal et al., 1993a, 1993b) it has been shown that the taxa having tricolporate pollen grains reveals their advanced status whereas taxa with polyad or colpate type of pollen grains shows its primitive status in the evolutionary scale. Thus the taxonomic assessment of the Brassicaceae is valuable diagnostic features in species delimitation.Brassica campestris having tricolporate pollen grains may be considered as in advanced status whereas Cassia occidentalis has primitive status in scale of evolution. The Brassica campestris are allergenic in nature (Chakroborty et al., 2005, Ghosh et al., 2007; Talukdar et al., 2012).Plant pollen is one of the most common causes of seasonal alle rgic dis ease worldwide. Parthenüm hysterophorus flower pollen has allergic effects on animal.

Among the collected taxa 9 shows trizonocolporate type, 4 shows polyzonoheterocolporate type and one exhibits tetrazonocolporate type of pollen grains. Tetrazonocolporate type of pollen grain is found in Argyreya species.All the taxainvestigated presently are characterized by more or less radially symmetrical, oblate to prolate type of pollen grains. Polle $n$ morphologically varies from lalongate-circular to lolongate type. The colpal margin of Cassia occidentals,Hibiscus panduriform is associated with exinal thickening. Structurally the exine of 18 species is crassinexinous with clearly discernible tegillate organization and the exine surface of the grains varies from faintly reticulate to reticulate type.

The present study is use ful in the preparation of a comple te polle $n$ calendar in diffe re nt seasons of the are a under investigation. A pollen calendar is useful for allergy clinics (Tilak, 2012). Pollen calendar is compiled based on data and knowledge obtained from field botanical survey of the area under investigation combined with data from aeropalynological survey (Agas he, 2012).

Thus the taxonomic assessment of the species investigated is possible considering the pollen parame ters. However, the data from other field of study like cytological, se rological, biochemical and immunological might strengthen this taxonomic assessment of the species. On the basis of pollen parameters the present investigated taxa like Parthenium hysterophorus, Plumbago, Lantana camara, Argyra spp., Cassia occidentalis and Brassica campestris having tricolporate pollen grains may be considered as in advanced status whereas Acacia auriculiformis has primitive status in scale of evolution. The colporate structures could be noticed very clearly in acetolysed pollen grains.

The prepared pollen slides of the taxa investigated may be used as reference slides for identifying the pollen grains captured from air. Aerobiologis ts reported that the pollen grains of Alstonia scholaris, Catharanthus roseus, Acacia auriculiformis, Moringa oleifera, Carica papaya, Mangifera indica and Brassica campestris are allergenic in nature (Chakroborty et al., 2005, Ghosh etal., 2007; Talukdar et al., 2012).

Plant pollen is one of the most common causes of seasonal allergic disease worldwide. Mango flowe r pollen has allergic effects on animal (Talukdar et al., 2012). The pollen grains showed the prominent spines throughout the surface of the exine and are subspheroidal in shape and tricolpate with three germinal apertures, which are common characteristic features of advanced dicot plants. 
Table - 1 - Light microscopic study of pollen of different plant

\begin{tabular}{|c|c|c|c|}
\hline $\begin{array}{l}\text { Sr. } \\
\text { No }\end{array}$ & Plant Name & Family & De scription of pollen grains \\
\hline 1 & Partheniumhys terophorus & Asteraceae & $\begin{array}{l}\text { Pollen grains are trizon ocolporate, subs phe roidal and } \\
\text { exines pinulose. }\end{array}$ \\
\hline 2 & Vernonia cineraria & Asteraceae & $\begin{array}{l}\text { Pollen grain are oblate sheroidal to occasionally } \\
\text { prolate she roidal ,trizonocolporate and echinocolpate } \\
\text { with } 15 \text { lacunae pe rforate microreticulate }\end{array}$ \\
\hline 3 & Vernonia cineraria & Asteraceae & $\begin{array}{l}\text { Pollen grains are is opolar large medium size } \\
\text { prolates pe roidal sublet. Pollen grains are } 3 \\
\text { colporatecolpus long the endopertures are lalongate. } \\
\text { The exine is thick se xine is sub chinolopate. }\end{array}$ \\
\hline 4 & Tridaxprocumbens & Asteraceae & Poratespinulous spheroid shape radial symmetry \\
\hline 5 & Zinnia pinnata & Asteraceae & Pantapora tespinolouse xine radial symmetry \\
\hline 6 & Ageratum conyzoides & Asteraceae & Prolates pinolour radial symmetry. \\
\hline 7 & Synedrellanudiflora & Asteraceae & Colpate striate surface bilateral symme try. \\
\hline 8 & Hibiscus panduriformis & Malvaceae & $\begin{array}{l}\text { Pollen is very large, round multiporate and exine is } \\
\text { echinate with long pointed spines. }\end{array}$ \\
\hline 9 & Malvas trumcoromandelianum & Malvaceae & Pollen are small tricolpate with echinateexine \\
\hline 10 & Sidamy sorensis & Malvaceae & Pantoporateechinate radial symmetry. \\
\hline 11 & Argyreia species & Convolvulaceae & $\begin{array}{l}\text { Pollen is small yellow round tricolpate with re ticulate } \\
\text { exine. }\end{array}$ \\
\hline 12 & Me rremia species & Convolvulaceae & Micro echina te perporate tecatemicros pines. \\
\hline 13 & Ipomoe a marginata & Convolvulaceae & Pantaporate pore sechinate radial symmetry. \\
\hline 14 & Smithia & Fabaceae & $\begin{array}{l}\text { Monocolpate exine obscure sub oblate bilateral } \\
\text { symmetry }\end{array}$ \\
\hline 15 & Desmodiums corpiurus & Fabaceae & $\begin{array}{l}\text { Pollen is medium to large size sphe roidal to oblate } \\
\text { sphe roidal in shape colpi zonal. }\end{array}$ \\
\hline 16 & Macroptiliumuniflorum & Fabaceae & $\begin{array}{l}\text { Square in center polyads in the form pollinia grains } \\
\text { group are } 16 .\end{array}$ \\
\hline 17 & Euphorbia ge nicula ta & Euphor biaceae & $\begin{array}{l}\text { Tricolpatecolpi clearly distinct exine rather thick } \\
\text { se xine, shape prolatespe rpidal grain medium size }\end{array}$ \\
\hline 18 & Euophorbiahirta & Euphor biaceae & $\begin{array}{l}\text { Tricolpate reticulate equatorial shape is proate sub } \\
\text { prolate polar shape circular grain colpi usually as } \\
\text { long exine sexine finely reticulate nexine thinner than } \\
\text { sexine thickness medium. }\end{array}$ \\
\hline 19 & Alterantheratenella & Amaranthaceae & $\begin{array}{l}\text { Pollen grain are mostly prolate or elongated } \\
\text { tectums pilate, granula te re ticulate or micro echinate } \\
\text { pollen grain are sphe roidal prolate triangular } \\
\text { subprolate }\end{array}$ \\
\hline 20 & Plumbagozeylanica & Plumbaginaceae & $\begin{array}{l}\text { Pollen class tricolpate sub transverse to semi } \\
\text { transverse exinesexine thicker than exineape rature } \\
\text { small to long eliptic acute ends reticulate in shape } \\
\text { bilateral symmetry. }\end{array}$ \\
\hline 21 & Lantana camera & Verbenaceae & $\begin{array}{l}\text { Tricolpate when triangular and some are square when } \\
4 \text { colporate. }\end{array}$ \\
\hline 22 & Cassia occidentalis & Caesalpinaceae & $\begin{array}{l}\text { Pollen are small round to triangular and tricolpate } \\
\text { with smooth exine }\end{array}$ \\
\hline 23 & Brassica napus & Bras sicaceae & $\begin{array}{l}\text { Pollen are small yellow, round and tricolpate with } \\
\text { reticulate exine }\end{array}$ \\
\hline 24 & Cardiospermumhalicacabum & Sapindaceae & $\begin{array}{l}\text { Pollen is symmetrical isopolarcolporatecolpate and } \\
\text { porate pollen moncolpate and monoporate. }\end{array}$ \\
\hline 25 & Tribulusterrestris & Zygophyllaceae & $\begin{array}{l}\text { Pollen grains are usually radially symmetrical or polar } \\
\text { three polyporatepantaporate. }\end{array}$ \\
\hline 26 & Boerhaviare pensvardiffusa & Nyctaginaceae & $\begin{array}{l}\text { Spheroidal pantoporate and the sexine as } \\
\text { tubuliferous and spinulose sexine is thick reticulate. }\end{array}$ \\
\hline 27 & Oxalis corniculata & Oxalidaceae & $\begin{array}{l}\text { Pollen type tricolpate surface pattern reticulate shape } \\
\text { prolate polar shape circular grain arrangement } \\
\text { monad. }\end{array}$ \\
\hline 28 & Centauriummeyeri & Ge ntianaceae & $\begin{array}{l}\text { Pollen grain sculpturing is striate reticulate three } \\
\text { colpate pollen grain striate reticulate exine } \\
\text { sculpturing. }\end{array}$ \\
\hline 29 & Peris trophe puniculata & Acanthaceae & Monoporate oblate radial symmetry. \\
\hline 30 & SonchusOleraceus & Asteraceae & $\begin{array}{l}\text { Shape in polarview is sphe roidal aperture type } \\
\text { lacunate pollen class trizonocolpate sculpturing is } \\
\text { echinate. }\end{array}$ \\
\hline
\end{tabular}


Plate No. -1. - Pollen morphology of some Asteraceae family members

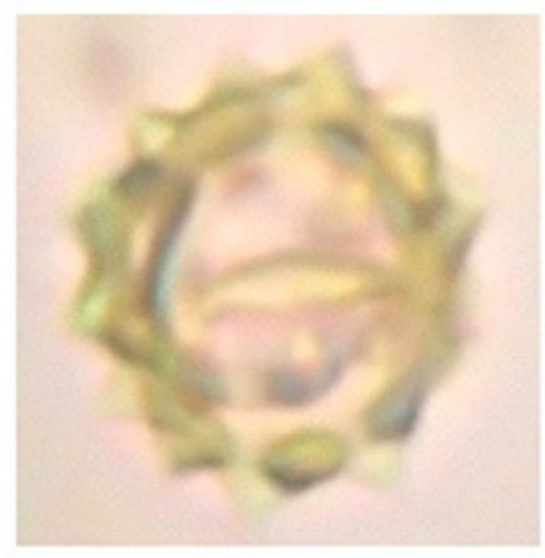

1) Parthenium hysterophorous

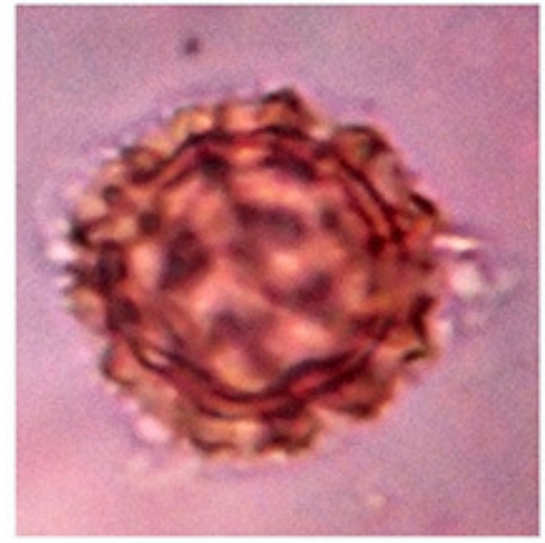

3) Vernonia cineraria

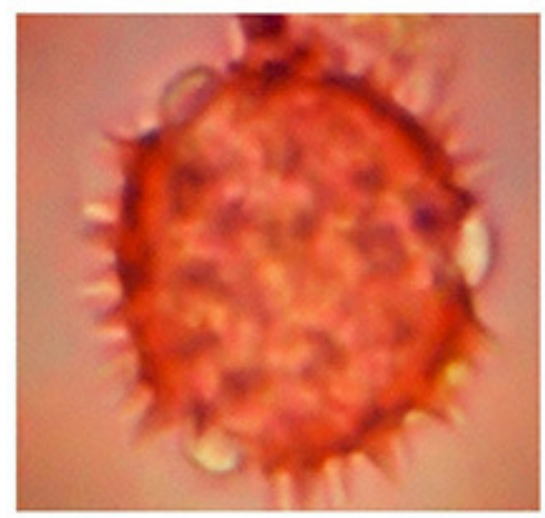

5) Zenia pinnata

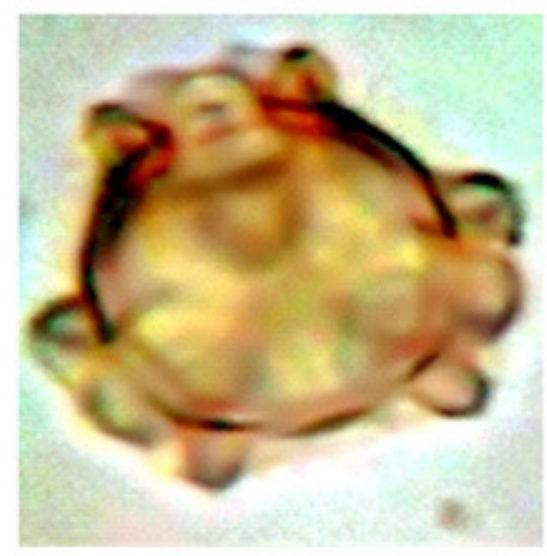

2) Launea sarmonosa

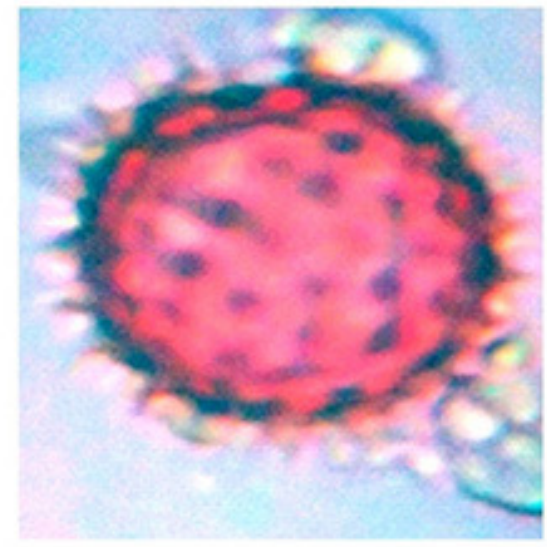

4) Tridax procumbens

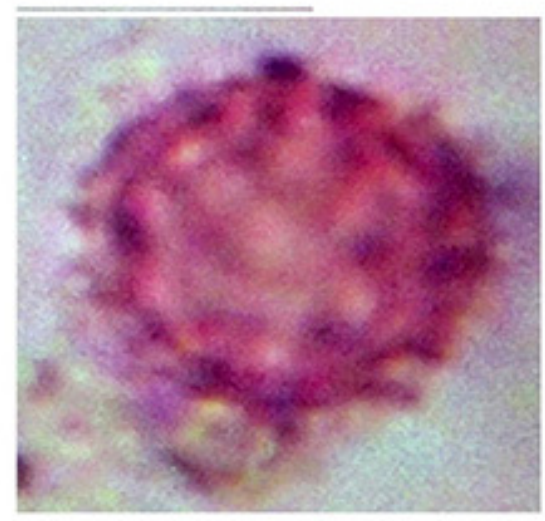

6) Ageratum conyzoides 
Plate No. - 2. - Pollen morphology of Asteraceae, Malvaceae \& Convolvulaceae family members

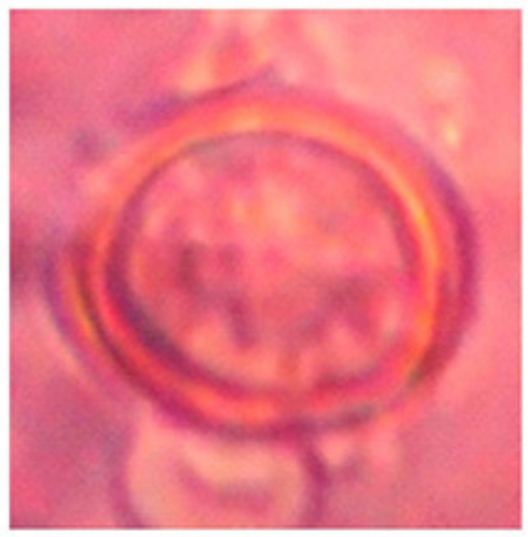

7)Synedrella nudiflora

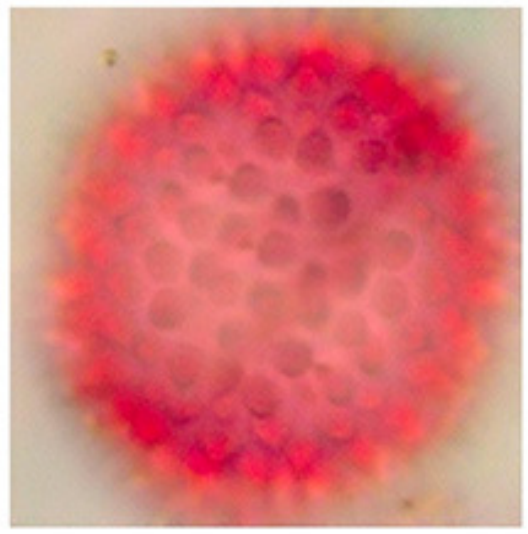

9) Malvastrum

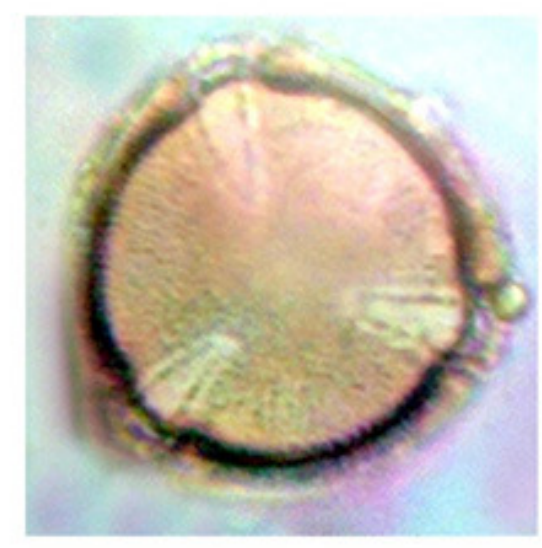

11) Argyreaya species

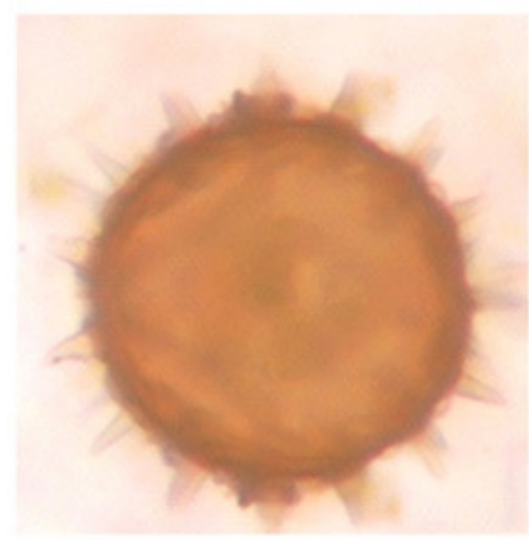

8) Hibiscus panduriformis

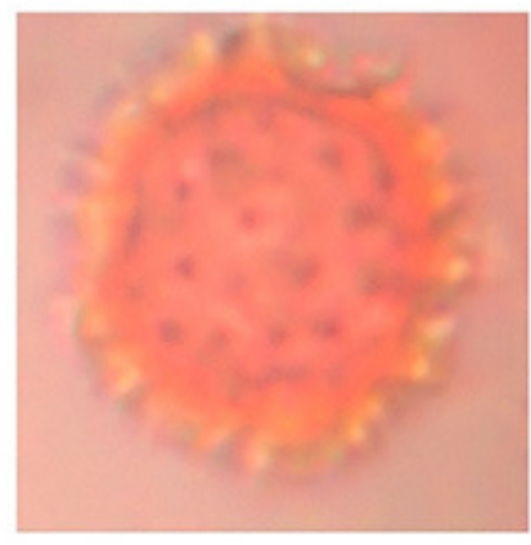

10) Sida mysorehsis

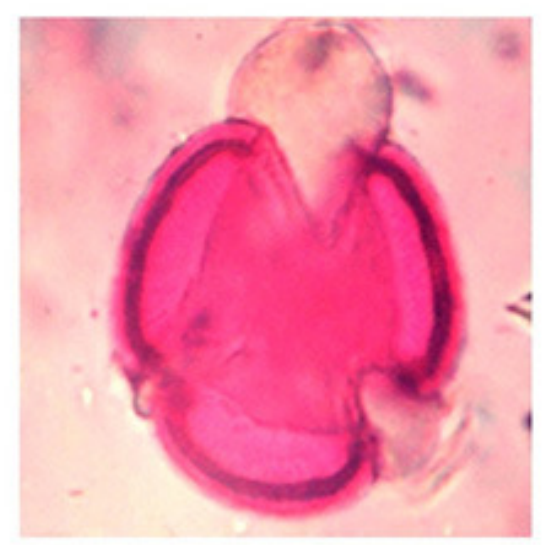

12) Merremia species 
Plate No. - 3. - Pollen morphology of Convolvulaceae, Fabaceae \& Euphorbiaceae family members

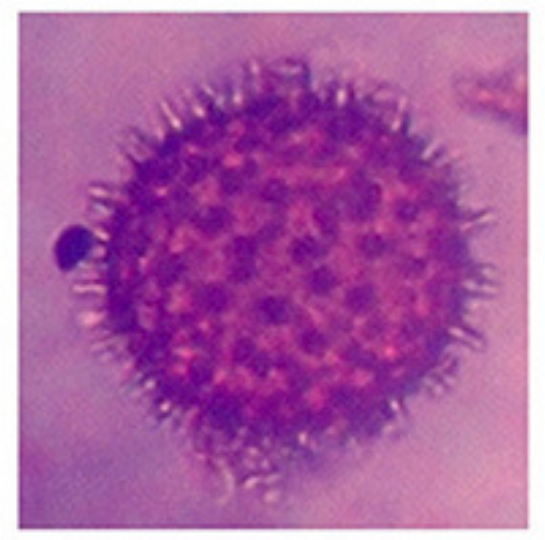

13) Ipomoea marginata

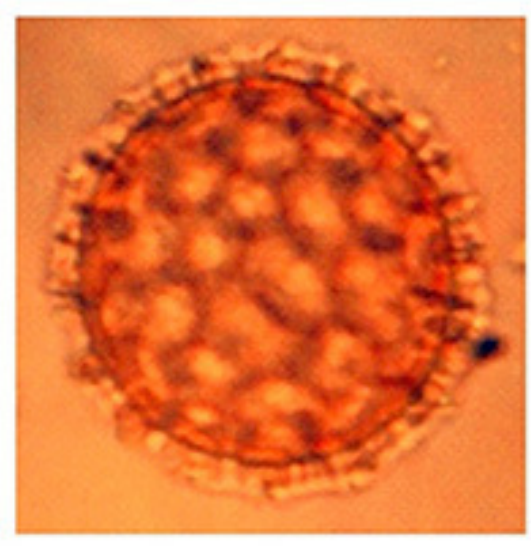

15) Desmodium scorpiurus

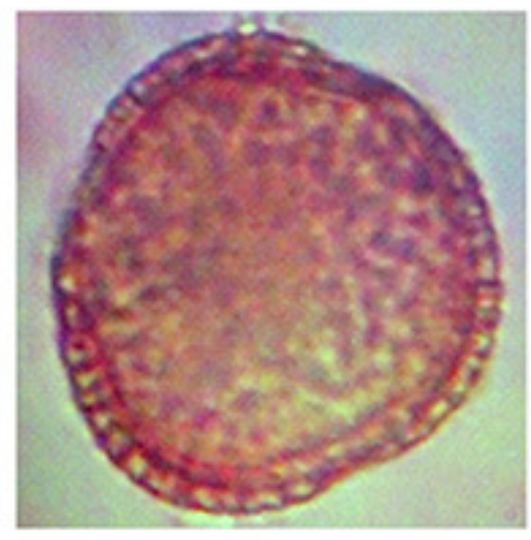

17) Euphorbia geniculate

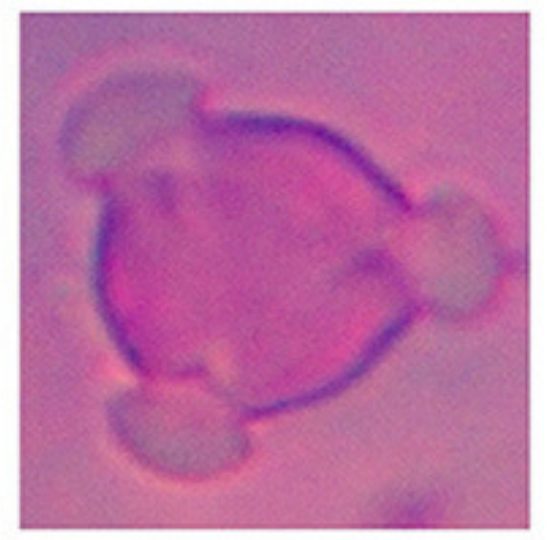

14) Smithea

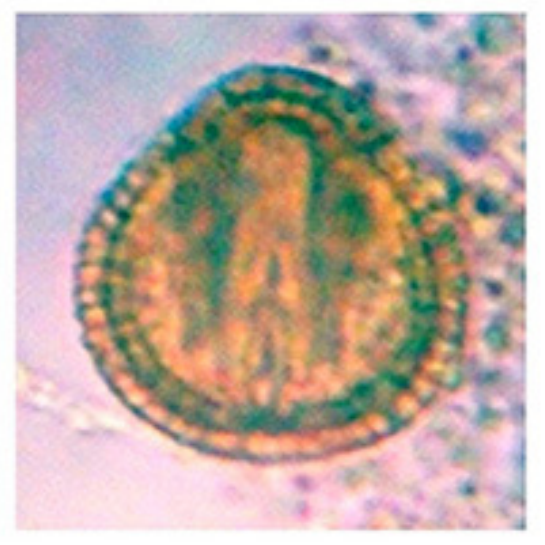

16) Macroptilium uniflorum

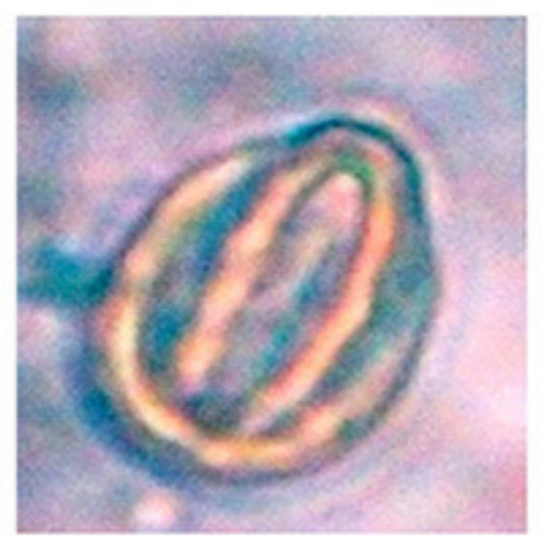

18) Euophorbia hirta 
Plate No. - 4. - Pollen morphology of different family members

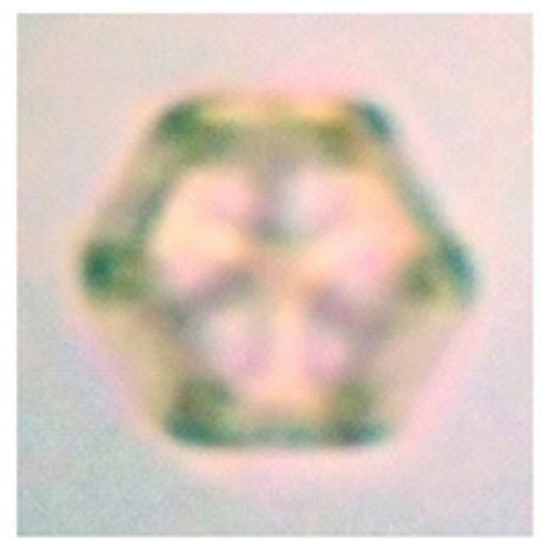

19) Alteranthera cicilis

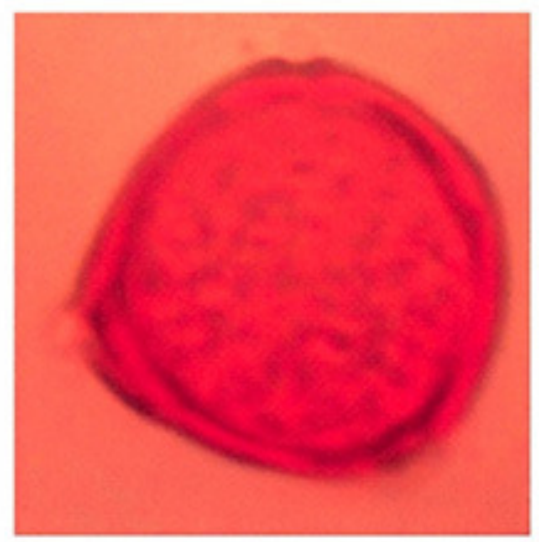

21) Lantana camera

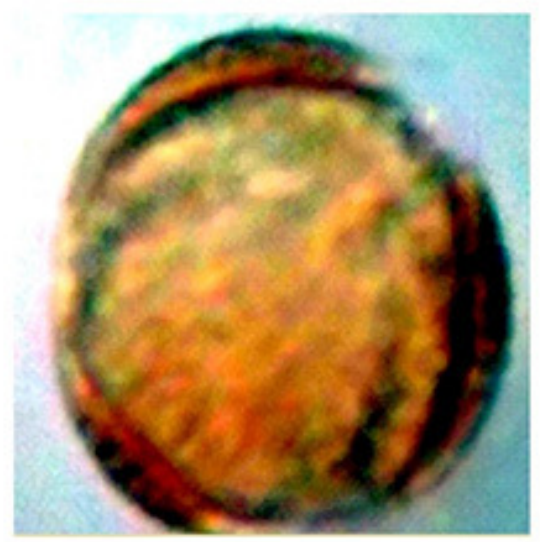

23) Brassica Camprstris

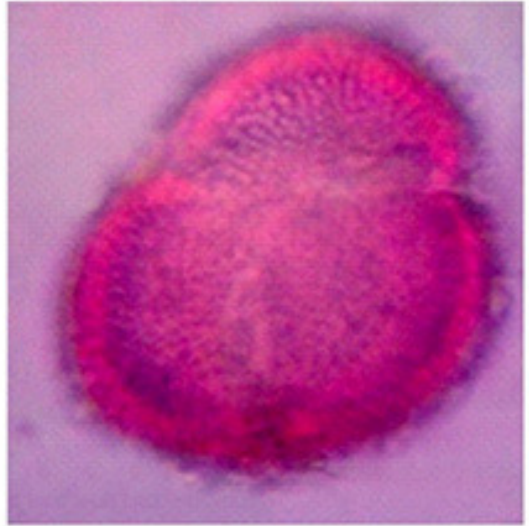

20) Plumbago zelanica

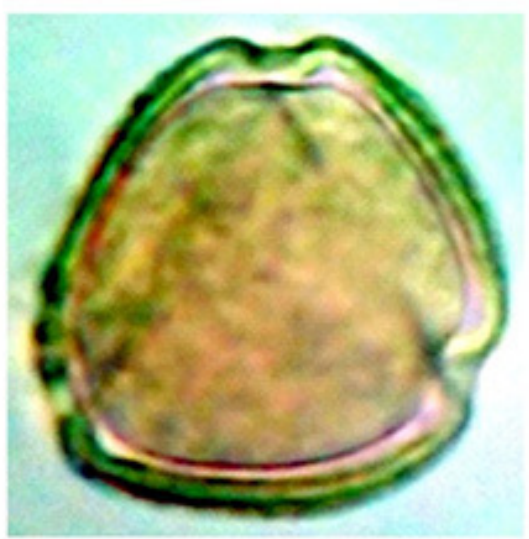

22) Cassia occidentalis

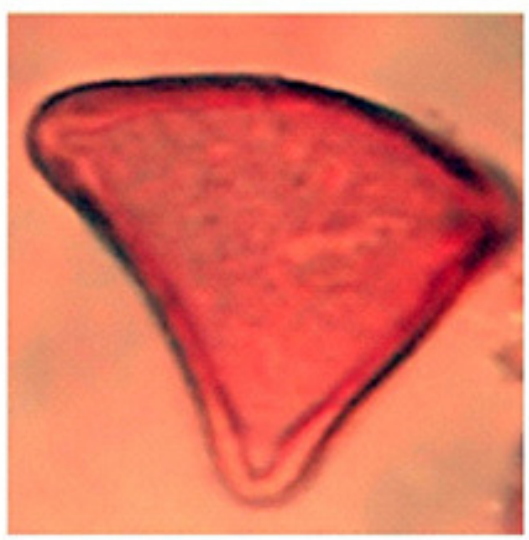

24) Cordospermum heliicabum 
plate No. - 5. - Pollen morphology of different family members

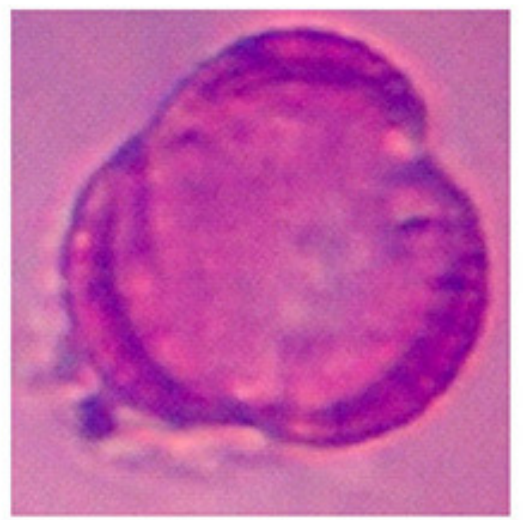

25) Tibulus tenestris

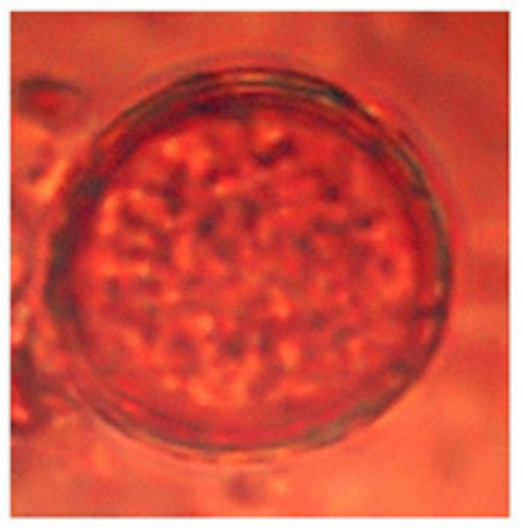

27) Oxalis conculata

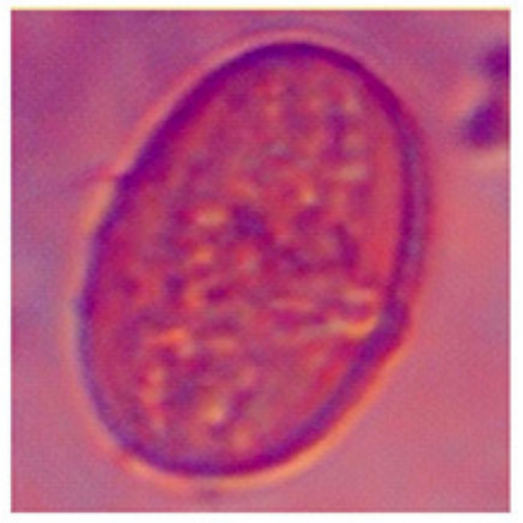

29) Peristrophe puniculata

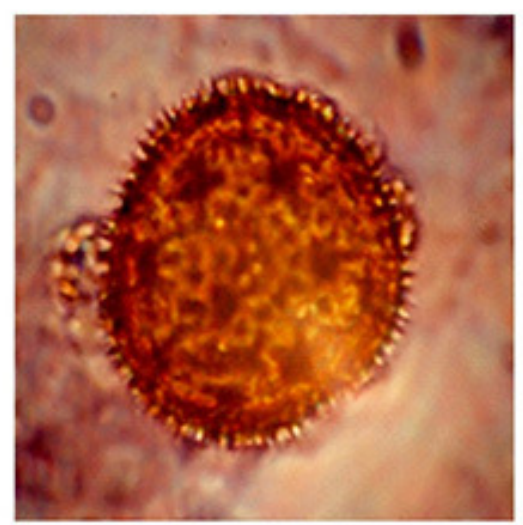

26) Borrhavia diffusa

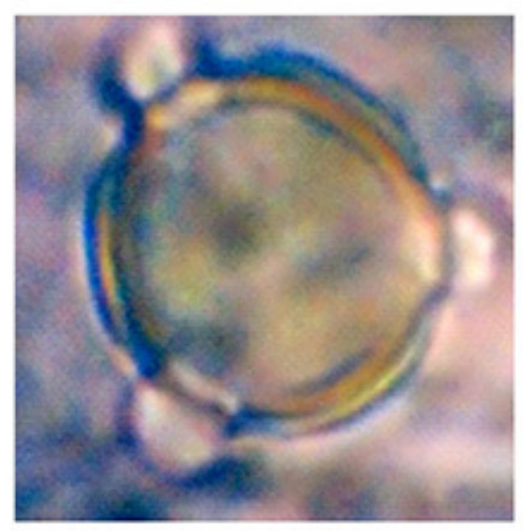

28) Centaurium meyeri

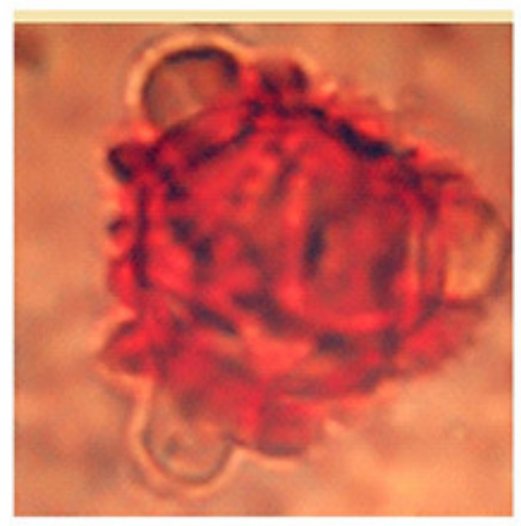

30) Sonchus Oleraceus 


\section{REFERENCES}

Agashe Shripad N. (2012) . Is Ae robiology Really Useful to Mankind. Proc.17th. National Confere nce of Indian Ae robiological Society on Impact of Airborne Microbes pp.3.

Bera S. K., Basumatary S. K., Dixit Swati (2007) Studies on pollen morphology and phonological characteristics of some economically important arborescent taxa of tropical forest,lower Brahmaputra valley, Assam, North East India. Journal of Palynology 43:1-19.

Bhattacharya, K., Majumdar, M. R., Gupta Bhattacharya, S. (2009). A text Book of Palynology. New Central Book Agency (P) Ltd., Kolkata, India.

Chakraborty, P., Ghosh D., Chowdhury, I., Ray I., Chatterjee, S., Chanda S., Gupta Bhattacharya, S. (2005). Ae robiological and Immunological studies on Carica papaya $\mathrm{L}$. Pollen: An aeroallergen from India. Allergy 60: 920-926.

Chanda S., Gupta-Bhattacharya S (2007). Allergy to Periwinkle pollen (Catharanthus roseus G. DON.) Ann Agric Environ Med. 14: 3943.

Chauhan, S. V. S., Goyal Rekha (2006). Pollen calendar of Agra city with special reference to allergenic significance. J Envtal Biol. 27: 275281.

Erdtman, G. (1952). Pollen morphology and plant taxonomy Angiosperm. (In Introduction to Palynology, Vol.1 Almqvist and Wiksell, Stockholm, Sweden.

Faegri J., Iversen K. (1964). Text Book of Pollen Analysis. 2nd. Ed. Munksgaard, Copenhagen, Denmark.

Ghosh D., Ray, Endrani Chanda S., GuptaBhattacharya, S. (2007). Allergy to Periwinkle pollen (Catharanthus roseus G. DON.) Ann Agric Environ Med. 14: 39-43.
Ghosh D., Ray, Endrani Chanda S., GuptaBhattacharya, S. (2007). Allergy to Periwinkle pollen (Catharanthus roseus G. DON.) Ann Agric Environ Med. 14: 39-43.

Keshavarzi M, Abassian S,Sheidai M (2012). Pollen morphology of the genus Clypeola (Brassicaceae) in Iran. Phytologia Balcanica 18 (1): 17-24.

Kremp G. O. W. (1965). Encyclopedia of Pollen Morphology. Univ. Arizona Press Tuscon, USA.

Moore P. D., Webb J. A. (1978). An illustrated guide to pollen analysis. Hodder and Stoughton, London, UK.

Pal J. K. (1992). Cytopalynological studies on some woody angiospermic taxa and effects of mutagen as well as polyploidizing chemical on cell nuclei. Ph.D the sis. Central library, Visha Bharati Unive rsity, Santiniketan.

Pal J. K., Datta B. K., Mandal S., Bhattacharya G. N. (1993a). Cyto-palynological Investigation in Cassia fistula L. Envt. Ecol. 11: 435-438.

Pal J. K., Mandal S., Bhattacharya G. N. (1993b). Cytopalynological studies in Shorea robusta Gaertn. F. Sci. Cult. 59:55-57.

Perveen A. (2006). A contribution to the pollen morphology of family Gramine ae. Wor App Sci J $1: 60-65$

Singh A. B., Kumar P. (2004). Aerial pollen diversity in India and the ir clinical significance in allergic diseases. Ind. J Clin. Biochem. 19:190201.

Talukdar G.,Hossain, Ismile, Ray, Nitai, Soma N. K., Kabir S. R., Biswas K. K., Roy N., Saha R. K. (2012). Allergen Protein from Mango (Mangifera indica) flowers pollen. Asian Pac J. Mol. Biol. Biotechnol

Tilak S. T. (2012). Renais sance of Aerobiology. Proc. 17th. National Conference of Indian AerobiologicalSociety on Impact of Airborne 